\title{
KEARIFAN LOKAL DALIHAN NA TOLU, NINIK MAMAK DAN KERAPATAN ADAT NAGARI DALAM MENJAGA KERUKUNAN ANTARUMAT BERAGAMA DI SUMATERA BARAT DAN SUMATERA UTARA
}

\author{
Sahrul \& Afrahul Fadhila Daulai \\ Universitas Islam Negeri Sumatera Utara Medan \\ Jl. Willem Iskandar Pasar V Medan Estate, Medan, Sumatera Utara, 20371 \\ e-mail: sahrul@uinsu.ac.id, afrahulfadhiladaulai@uinsu.ac.id
}

\begin{abstract}
Abstrak: Studi ini menganalisis peran kearifan lokal dalihan na tolu, ninik mamak dan Kerapatan Adat Nagari dalam menjaga kerukunan antarumat beragama di Pasaman Barat dan Kabupaten Mandailing Natal. Penelitian ini merupakan penelitian kualitatif dimana data diperoleh melalui wawancara, pengamatan dan studi dokumen. Teknik analisis data menggunakan model Miles dan Huberman. Penelitian ini menemukan bahwa kearifan lokal dalihan na tolu di Kabupaten Madina berperan penting dari segi agama, budaya dan sosial dalam menjaga kerukunan antarumat beragama, karena menerapkan nilai budaya religius, menjaga kekerabatan, humajuon, hasangapon, uhum, pengayom kepada masyarakat dan mengelola konflik. Sedangkan di Kabupaten Pasaman Barat, peranan ninik mamak dan Kerapatan Adat Nagari belum optimal di dalam melaksanakan fungsinya karena minimnya dialog dan kerjasama dengan Forum Kerukunan Umat Beragama.
\end{abstract}

\begin{abstract}
Local Wisdom Dalihan Na Tolu, Ninik Mamak and Kerapatan Adat Nagari in Maintaining Inter-religious Harmony in West and North Sumatera. This study aims to analyze the role of local wisdoms in maintaining inter-religious harmony in West Pasaman and Mandailing Natal Regency. This research is a qualitative study in which data is obtained through interviews, observations and document studies. Data analysis techniques employ the Miles and Huberman models. This study proposed that the local wisdoms of dalihan na tolu in Madina Regency, play an important role of religion, social and culture in maintaining interreligous harmony, since it apply seven religious values of humajuon, hasangapon, uhum, and managing the conflict. Meanwhile, in the West Pasaman the role of the ninik mamak and the Kerapatan Adat Nagari still need to be optimized in safeguarding religious harmony which might arise from the lack of dialogue and cooperation with Religious Harmony Forum (FKUB).
\end{abstract}

Kata Kunci: Mandailing, Minangkabau, kearifan lokal, dialog, agama-agama 


\section{Pendahuluan}

Masyarakat Indonesia sangat plural dari segi agama, etnik, bahasa, budaya, dan golongan, sebuah sunatullâh di alam semesta yang tidak mungkin dipungkiri oleh manusia. Bagi kaum beriman, ini merupakan tanda-tanda kebesaran Allah di muka bumi. Bagi kaum yang tidak beriman, hal ini luput dari pengamatannya bahkan dianggap hal biasa saja. Berkaitan dengan hal itu, Allah SWT. berfirman sebagai berikut: Wahai manusia! Sungguh, Kami telah menciptakan kamu dari seorang laki-laki dan seorang perempuan, kemudian Kami jadikan kamu berbangsa-bangsa dan bersuku-suku agar saling mengenal. Sungguh yang paling mulia di antara kamu di sisi Allah ialah orang yang paling takwa. Sungguh Allah Maha Mengetahui dan Maha Teliti.

M. Amin Abdullah mengatakan pluralitas (keanekaragaman) agama adalah sebuah kenyataan historis yang tidak mungkin disangkal oleh siapa pun. ${ }^{1}$ Pendapat yang sama juga dikatakan oleh Nurcholish Madjid dalam Dadang Kahmad bahwa pluralitas adalah sunatullah yang tidak mungkin berubah dalam kehidupan manusia. Barangsiapa yang meniadakan sunatullah berarti tidak mengakui kemahakuasaan Allah. ${ }^{2}$ Al-Qur'an sendiri mengakui adanya pluralitas agama dan hidup berdampingan secara damai. ${ }^{3}$

Pengakuan terhadap pluralitas dinilai sangat penting dalam kehidupan berbangsa dan bernegara. Karena keanekaragaman adalah modal utama untuk merajut kebersamaan, interaksi sosial dan membangun semangat toleransi antarumat beragama. Tujuannya adalah untuk membentuk suasana keagamaan yang harmonis dan sebagai upaya antisipasi terjadi konflik agama dan sosial. Karena belajar dari berbagai kasus konflik agama dan sosial di Indonesia. Faktor pemicu di antaranya tidak mengakui pluralitas secara utuh. Masih banyak di antara penganut agama merasa agamanya yang paling benar dan penganut agama lain dipandang salah dan sesat.

Sebagai wujud pengakuan pluralitas ditegaskan dalam Undang-Undang Dasar Tahun 1945 Pasal 28 E ayat menyatakan bahwa (2) Setiap orang bebas memeluk agama dan beribadat menurut agamanya, memilih pendidikan dan pengajaran, memilih pekerjaan, memilih kewarganegaraan, memilih tempat tinggal di wilayah negara dan meninggalkannya serta berhak untuk kembali. Selanjutnya pada Bab XI Agama pasal 29 ayat (1) Negara berdasar atas Ketuhanan Yang Maha Esa. Ayat (2) Negara menjamin kemerdekaan tiap-tiap penduduk untuk memeluk agamanya masing-masing dan untuk beribadat menurut agamanya dan kepercayaannya itu. ${ }^{4}$

${ }^{1}$ M. Amin Abdullah, Studi Agama Normativitas Atau Historitas (Yogyakarta: Pustaka Pelajar, 1996), h. 5.

${ }^{2}$ Dadang Kahmad, Sosiologi Agama (Bandung: Rosdakarya, 2002), h. 174.

${ }^{3}$ Umi Sumbulah dan Nurjanah, Pluralisme Agama (Malang: UIN Maliki Press, 2013), h. 10.

${ }^{4}$ Majelis Permusyawaratan Rakyat, Undang-Undang Dasar Negara Republik Indonesia (Jakarta: Sekretariat Jenderal MPR RI 2015), h. 161. 
Di Indonesia diakui enam agama secara resmi yaitu Islam, Kristen Katolik, Protestan, Hindu, Buddha dan Konghucu. Didasarkan pada sensus penduduk tahun 2010, penganut agama Islam adalah kelompok mayoritas (87,18\%), lalu Kristen Protestan (6,96\%,), Kristen Katolik (2,91\%) dan Hindu (1,69\%). Sedangkan kelompok minoritas adalah Konghucu (0,05\%). Di Sumatera Barat, penganut agama Islam sebanyak 97,42\%, Protestan 1,43\%, Katolik 0,83\%, dan Buddha 0,07\%. Di Sumatera Utara, penganut agama Islam sebanyak 66,09\%, Protestan 27,03\%, Katolik 3,97\%, Buddha 2,34\%, dan Hindu 0,11\%.

Di mata pemerintah, pengaturan tentang agama tidak cukup melalui Undang-Undang Dasar tahun 1945 saja tetapi harus dibantu oleh Surat Keputusan Bersama (SKB) yang ditandatangani oleh Menteri Agama dan Menteri Dalam Negeri nomor 9 dan 8 tahun 2006. Isi keputusan tersebut sebagai berikut: Pasal 1 ayat (1) Kerukunan umat beragama adalah keadaan hubungan sesama umat beragama yang dilandasi toleransi, saling pengertian, saling menghormati, menghargai kesetaraan dalam pengamalan ajaran agamanya dan kerjasama dalam kehidupan bermasyarakat, berbangsa dan bernegara dalam Negara Kesatuan Republik Indonesia berdasarkan Pancasila dan Undang-Undang Dasar Negara Republik Indonesia Tahun 1945. Ayat (2) Pemeliharaan kerukunan umat beragama adalah upaya bersama umat beragama dan pemerintah di bidang pelayanan, pengaturan, dan pemberdayaan umat beragama. Ayat (6) Forum Kerukunan Umat Beragama (FKUB) adalah forum yang dibentuk oleh masyarakat dan difasilitasi oleh pemerintah dalam rangka membangun, memelihara dan memberdayakan umat beragama untuk kerukunan dan kesejahteraan.

Bagi penganut agama tidaklah cukup memadakan Undang-Undang Dasar 1945, dan Surat Keputusan Bersama (SKB) Nomor 9 dan 8 tahun 2006. Namun, perlu dilibatkan lembaga kearifan lokal dalam menjaga kerukunan antarumat beragama. Di Sumatera Utara khususnya di Kabupaten Madina, etnik Mandailing 5 punya Dalihan Na Tolu (DNT). Basyral Hamidiy Harahap menyebutnya sistem kekerabatan patrilineal (garis keturunan

${ }^{5}$ Etnik Mandailing cenderung beragama Islam. Dari aspek organisasi, ulama-ulama Mandailing berafiliasi dengan Al Jam'iyatul Washliyah dan Nahdlatul Ulama. Lihat kajian ini dalam Mhd. Syahnan, "Nahdlatul Ulama Scholar in Mandailing Land: A Biography of Shaykh Ali Hasan Ahmad ad-Dary," dalam Journal of Contemporary Islam and Muslim Societies, Vol. 3 No. 1, 2019; Abbas Pulungan, "Nahdlatul Ulama di Luar Jawa: Perkembangan di Tanah Mandailing," dalam Journal of Contemporary Islam and Muslim Societies, Vol. 2 No. 1, 2018; Ja'far Ja'far, "Tarekat dan Gerakan Sosial Keagamaan Shaykh Hasan Maksum," dalam Teosofi: Jurnal Tasawuf dan Pemikiran Islam, Vol. 5, No. 2, 2015, 269-293; Ja'far Ja'far, "Respon Dewan Fatwa Al-Jam'iyatul Washliyah Terhadap Isu Akidah dan Syariah di Era Global," dalam AlManahij: Jurnal Kajian Hukum Islam, Vol. 10, No. 1, 2017, 97-118; Jafar Jafar, "Al Jam'iyatul Washliyah dan Problem Kepemimpinan Non Muslim dan Perempuan," dalam Ahkam: Jurnal Ilmu Syariah, Vol. 17, No. 2, 2017; Ja'far Ja'far, "Respons Al Jam'iyatul Washliyah Terhadap Terorisme," dalam Akademika: Jurnal Pemikiran Islam, Vol. 22, No. 1, 2017; Ja'far Ja'far, "Peran Al Jam'iyatul Washliyah dalam Merevitalisasi Madhhab Shafi'i di Era Kontemporer," dalam Justicia Islamica: Jurnal Kajian Hukum dan Sosial, Vol. 13, No. 1, 2016. 
ayah) dan semua kerabat pria. ${ }^{6}$ Di Sumatera Barat punya kearifan lokal yaitu Ninik Mamak dan Kerapatan Adat Nagari, disingkat (KAN).

Dalihan $\mathrm{Na}$ Tolu (DNT) dimaknai tiga tungku sejarangan. $^{8}$ Secara bahasa, dalihan artinya tungku, na berarti yang (kata penghubung), tolu artinya tiga. Terdiri atas mora, kahanggi dan anak boru. Mora dimaknai kelompok kerabat pemberi istri (wife giver) dalam tradisi etnik Batak Toba disebut hula-hula. Kahanggi ialah karena satu keturunan atau marga yang sama. Bisa juga dipahami garis keturunan laki-laki dari keturunan cikal bakal laki-laki pula. ${ }^{9}$ Dalam tradisi etnik Batak Toba disebut dongan sabituha (dilahirkan dari rahim ibu yang sama). Sedangkan anak boru yaitu menantu dari mora atau kerabat yang mengambil istri (wife taker). Ketiga unsur tersebut punya fungsi dan saling bersinergi dalam bidang adat, pesta pernikahan, pesta budaya, kekerabatan dan menjaga kerukunan antara penganut agama dalam kehidupan bermayarakat.

Ninik Mamak dan Kerapatan Adat Nagari (KAN). Ninik Mamak disebut pengetua adat di jorong dan disebut juga datuk. Dari segi struktur adat sebenarnya masuk dalam ruang lingkup tiga sejarangan yaitu Ninik Mamak, alim ulama dan cerdik pandai. Ketiga unsur inilah yang saling bersinergi dalam kehidupan masyarakat. Landasannya ialah adat basandi syarak, syarak basandi kitabullah. Dulu, fungsinya lebih banyak mengurusi tentang sengketa tanah, masalah keluarga dan kekerabatan. Fungsinya kini semakin luas yaitu berperan dalam menjaga interaksi sosial dan kerukunan antarumat beragama. Peranan ini tidak terlepas karena pesatnya pembangunan di daerah, banyaknya penganut agama non muslim, perkebunan sawit dan cepatnya perubahan sosial di Pasaman Barat. Artikel ini akan mengkaji bagaimana peranan kearifan lokal etnik Mandailing dan Minangkabau tersebut dalam menjaga kerukunan antarumat beragama.

\section{Teori-Teori Sosiologi}

\section{Teori Peranan dan Status}

Peranan diartikan sama dengan kedudukan atau fungsi. Faktor pembentuknya yaitu apabila dipenuhi hak dan kewajiban. Pada kenyataannya banyak di antara manusia lebih banyak menuntut haknya jika dibanding dengan melaksanakan kewajibannya.

${ }^{6}$ Basyral Hamidy Harahap, Madina yang Madani (Panyabungan: Pemerintah Daerah Kabupaten Madina, 2004), h. 354.

${ }^{7}$ Beberapa peneliti mengkaji masalah ini, lihat misalnya Lelya Hilda, "Revitalisasi Kearifan Lokal Dalihan Na Tolu Masyarakat Muslim Mandailing Dalam Menjaga Harmonisasi Lingkungan Hidup," dalam MIQOT: Jurnal Ilmu-ilmu Keislaman, Vol. 42, No. 2, 2018; Adison Adrian Sihombing, "Mengenal Budaya Batak Toba Melalui Falsafah "Dalihan Na Tolu" (Perspektif Kohesi dan Kerukunan)," dalam Jurnal Lektur Keagamaan, Vol. 16, No. 2, 2018, pp. 347-371.

${ }^{8}$ Pandapotan Nasution, Adat Budaya Mandailing Dalam Tantangan Zaman (Medan: Porkala, 2005), h. 80.

${ }^{9}$ Basyral Hamidy Harahap, Madina, h. 354. 
Idealnya, kedua harus sama-sama ditunaikan. Sedangkan status ialah keadaan seseorang dalam lingkup keluarga, masyarakat bahkan negara. Ada tiga bentuk status, pertama, status karena keturunan. Misal, karena ayah dan ibu keturunan bangsawan maka anak jadi keturunan bangsawan. Kedua, karena prestasi yaitu berdasarkan kinerja dan prestasi. Ketiga, status sosial karena diberikan oleh masyarakat. ${ }^{10}$ Misal, karena perannya cukup besar maka diberi status sosial terhormat seperti ulama, kiai, ustad, tuan guru, khalifah.

\section{Struktural Fungsional}

Menurut teori ini ada beberapa asumsi dasar masyarakat. Pertama, masyarakat merupakan satu kesatuan yang utuh, saling bersinergi satu sama lain dan saling mempengaruhi. Ibarat sebuah bangunan yang terdiri atas elemen-elemen. Andainya satu elemen tidak berfungsi dengan baik maka akan mempengaruhi elemen lain. Kedua, setiap elemen akan eksis kalau bekerja sesuai dengan fungsinya dan ikut serta berperan aktif dalam komponennya. Ketiga, seluruh elemen di masyarakat punya komitmen yang sama untuk menjaga keutuhan, tidak boleh saling mengklaim elemennya lebih berperan dan lebih kuat. Keempat, seluruh elemen masyarakat dipastikan memiliki persamaan dan perbedaan serta bersifat heterogen (beraneka ragam). Kelima, perubahan sosial di masyarakat bagaimana pun juga sulit dihindari karena dipengaruhi oleh semakin rasional manusia, terbuka, lingkungan, media dan majunya ilmu pengetahuan.

\section{Teori Konflik Sosial}

Menurut teori ini, masyarakat berkembang dan maju karena konflik atau persaingan baik dalam bidang pendidikan, ekonomi, sosial, kesehatan, komunikasi, budaya dan politik. Persaingan tersebut bukanlah untuk saling menghancurkan tetapi persaingan sehat untuk meningkatkan daya berpikir, sumber daya manusia, merubah nasib dan menjalin solidaritas sosial.

\section{Teori Interaksi Simbolik}

Menurut teori, masyarakat yang maju ialah masyarakat yang membangun solidaritas sosial sesama, interaksi sosial, bersikap terbuka, mudah menerima persamaan dan perbedaan dan menggunakan simbol-simbol dalam berkomunikasi. Nasrullah Nazsir berpendapat bahwa yang membentuk interaksi simbolik adalah karena individu dipengaruhi oleh faktor keluarga dan lingkungan. Bagaimana pun hebatnya manusia tidak bisa hidup sendirian tetapi harus bermasyarakat.

${ }^{10}$ Kamanto Sunarto, Pengantar Sosiologi (Jakarta: Lembaga Penerbit Fakultas Ekonomi Universitas Indonesia, 2004), h. 53. 
Selain beberapa teori tersebut di atas, Islam sebagai agama tauhid kaya tentang teoriteori sosial Islam. Pertama, orang mukmin itu bersaudara (Q.S. al-ㅍujurat/49: 10). Berdasarkan ayat tersebut, orang beriman itu adalah bersaudara meskipun beda suku, bangsa, golongan, budaya, bahasa dan status sosial. Tali pengikatnya adalah akidah Islam. Jika terjadi perbedaan paham dan perselisihan maka dianjurkan untuk saling memahami, damai dan tidak saling menghancurkan. Landasannya adalah ketakwaan. Kalau itu dasarnya maka Alah SWT. . akan mencurahkan rahmatnya kepada manusia. Kedua, kontrol sosial (Q.S. Âli 'Imrân/3: 104). Dakwah yang dilaksanakan untuk mengajak manusia kepada jalan kebaikan dan berbuat makruf serta mencegah manusia dari perbuatan mungkar merupakan bagian dari kontrol sosial di masyarakat. Tugas ini tergolong mulia dan lebih baik dilakukan secara lembaga dari pada individual. Keunggulannya secara manajemen dakwah mudah direncanakan, diorganisir, digerakkan dan dievaluasi. Sedangkan kelemahan secara individual dakwah cenderung bersifat monoton dan menurut selera darinya. Ketiga, teori kebebasan beragama (Q.S. al-Kâfirûn/109: 1-6). Menurut ayat tersebut, Allah SWT. memberi kebebasan beragama kepada manusia untuk memilih agama tetapi agama yang paling benar di sisi Allah adalah Islam sebagai agama tauhid yang diwahyukan kepada Nabi Muhammad SAW., landasan al-Qur'an dan Sunnah, menjadi pedoman hidup di dunia dan akhirat. Prinsip utamanya adalah tidak boleh memaksakan agama Islam kepada penganut agama lain dan bagimu agamamu dan bagiku agamaku.

\section{Metode Penelitian}

Pendekatan yang digunakan dalam penelitian ini adalah kualitatif yang berupaya menggambarkan hasil penelitian dalam bentuk kata-kata tertulis yang merupakan hasil dari wawancara, pengamatan langsung dan studi dokumentasi. Ciri pendekatan ini bersifat rasional, idealis, humanis, kritis dan empiris. ${ }^{11}$ Dewi Sadiah mengatakan penelitian kualitatif landasan berpikirnya filsafat positivisme digunakan untuk meneliti objek alamiah, peneliti sebagai instrumen, pengambilan sampel sumber data secara purpossive dan snowball, analisis data bersifat induktif dan hasil penelitian yang diperoleh lebih ditekankan pada makna dari pada generalisasi. ${ }^{12}$

Dalam upaya memperoleh data dilakukan dua metode pengumpul data yaitu wawancara dan pengamatan. Wawancara yaitu dengan tokoh agama, adat dan pengurus Kerukunan Umat Beragama (FKUB). Dibuat sejumlah pertanyaan dan dialog yang intens antara peneliti dan informan penelitian. Pengamatan di sini cenderung bersifat partisipatif untuk melihat kearifan lokal yang dimiliki etnik Mandailing di Kabupaten Madina dan etnik Minangkabau di Kabupaten Pasaman Barat.

${ }^{11}$ M. Burhan Bungin, Penelitian Kualitatif (Jakarta: Kencana, 2007), h. 4-5.

${ }^{12}$ Dewi Sadiah, Metode Penelitian Dakwah (Bandung: Rosdakarya, 2015), h. 19. 
Dalam penerapannya di lapangan tentu melihat naskah-naskah Dalihan Na Tolu dan Ninik Mamak dan Kerapatan Adat Nagari berupa tulisan, dokumen, catatan harian dan didukung oleh buku-buku yang berkaitan di perpustakaan. Buku-buku ini dipandang cukup penting untuk mendukung hasil wawancara dan pengamatan.

Teknik analisis data yang dilakukan yaitu dengan reduksi data, display data, kesimpulan dan verifikasi. Reduksi data maksudnya diawali dengan pekerjaan merangkum, memilahmilah data pokok, fokus pada data-data penting, membuang data yang tidak diperlukan. Display data (penyajian data) yaitu memaparkan dalam bentuk narasi (uraian) secara logis, sistematis dan pendekatan induktif. Maksudnya menggunakan cara berpikir dari yang khusus ke umum. Kesimpulan yaitu menyimpulkan hasil penelitian yang akan menjawab rumusan dan tujuan penelitian. Sedangkan verifikasi yaitu penelitian yang dilakukan dapat diuji kebenarannya secara objektif oleh peneliti maupun peneliti lain.

\section{Hasil dan Pembahasan}

\section{Mengenal Kabupaten Madina}

Kabupaten Mandailing Natal disingkat Madina berada pada posisi 0.10-1 50 Lintang Utara dan 98.10-100.10 Bujur Timur. Diresmikan menjadi sebuah kabupaten permanen yaitu tanggal 9 Maret 1999 dan secara resmi berpisah dari Kabupaten Tapanuli Selatan. Ibukotanya yaitu Panyabungan. Luas wilayah 6.620,70 km persegi atau 9,23\% dari luas wilayah Provinsi Sumatera Utara. ${ }^{13}$ Batas wilayah sebagai berikut. Sebelah Utara berbatasan dengan Kabupaten Tapanuli Selatan. Sebelah Selatan berbatasan dengan Kabupaten Pasaman. Sebelah Barat berbatasan dengan Samudera Indonesia. Sebelah Timur berbatasan dengan Kabupaten Pasaman Barat.

Secara demografis, jumlah penduduk 430.894 jiwa. Tingkat kepadatan penduduk 65,08 jiwa/per km. Terdiri atas 377 desa atau kelurahan dan 23 kecamatan, meliputi Kecamatan Batahan, Kecamatan Batang Natal, Kecamatan Bukit Malintang, Kecamatan Huta Bargot, Kecamatan Kota Nopan, Kecamatan Lingga Bayu, Kecamatan Lembah Sorik Marapi, Kecamatan Muara Batang Gadis, Kecamatan Muara Sipongi, Kecamatan Naga Juang, Kecamatan Natal, Kecamatan Pakantan, Kecamatan Panyabungan Barat, Kecamatan Panyabungan Kota, Kecamatan Panyabungan Selatan, Kecamatan Panyabungan Timur, Kecamatan Panyabungan Utara, Kecamatan Puncak Sorik Marapi, Kecamatan Ranto Baek, Kecamatan Siabu, Kecamatan Sinunukan, Kecamatan Tambangan, Kecamatan Ulu Pungkut dan Kecamatan Batang Natal.

Kabupaten Madina terdiri atas beberapa etnik seperti pada tabel berikut:

\footnotetext{
${ }^{13}$ Basyral Hamidy Harahap, Madina yang Madani (Madina: Pemerintah Daerah Kabupaten Madina, 2004), h. 13.
} 
Tabel 1

Jumlah Penduduk Berdasarkan Etnik

\begin{tabular}{|c|l|c|}
\hline NOMOR & \multicolumn{1}{|c|}{ NAMA ETNIK } & PERSENTASE \\
\hline 1 & Mandailing & $80,2 \%$ \\
\hline 2 & Melayu & $6,74 \%$ \\
\hline 3 & Jawa & $6,3 \%$ \\
\hline 4 & Toba/Tapanuli & $3,2 \%$ \\
\hline 5 & Minangkabau & $1,13 \%$ \\
\hline 6 & Aceh & $0,7 \%$ \\
\hline 7 & Karo & $0,03 \%$ \\
\hline 8 & Nias & $0,26 \%$ \\
\hline 9 & Simalungun & $0,2 \%$ \\
\hline 10 & Pakpak & $0,01 \%$ \\
\hline 11 & Dan lainnya & $2,22 \%$ \\
\hline
\end{tabular}

Didasarkan pada tabel tersebut di atas, etnik Mandailing adalah mayoritas, terbanyak kedua adalah etnik Melayu, terbanyak ketiga yaitu Jawa, terbanyak keempat yaitu etnik Batak Toba dan yang paling kecil jumlahnya yaitu etnik Pakpak, sering juga dikatakan etnik Dairi, karena berasal dari Kabupaten Dairi. Bahasa pengantar seharihari pada umumnya adalah bahasa Mandailing. Sebab, masing-masing etnik pandai berbahasa Mandailing karena faktor lingkungan, sekolah, kedai kopi, pergaulan di masyarakat dan kantor.

Dari aspek agama, di Kabupaten Madina, penganut agama yaitu Islam (386.771 jiwa/96,79\%), Kristen Protestan (12.452 jiwa/3,10\%), Katolik (454 jiwa/0,11\%), penganut agama Hindu (10 jiwa/0,005\%), Buddha (16jiwa/ 0,006\%) dan penganut agama Konghucu tidak ada. Sebab, penganut agama Buddha termasuk di dalamnya penganut agama Konghucu. Mereka adalah etnik Tionghoa, pada umumnya berprofesi sebagai pedagang. Mengapa cukup kecil jumlahnya? Karena pemerintah Kabupaten Madina tidak membolehkan masuknya pengusaha Tionghoa sebab akan menguasai bidang ekonomi dan pedagang lokal akan kalah bersaing. Kebijakan ini dinilai positif bukan diskriminatif tetapi justru lebih berpihak kepada masyarakat lokal yang sejak dulu secara bersama-sama membangun kota Panyabungan.

Penganut agama memerlukan rumah ibadah seperti masjid, musala, gereja dan vihara. Berdasarkan hasil observasi, ditemukan bahwa ada 25 unit gereja. Sedangkan masjid berjumlah 404 unit dan 202 unit musala atau surau. Banyaknya jumlah masjid dan musala tersebut karena mayoritas penduduk adalah agama Islam. Keadaan bangunan masjid kelihatan cukup permanen, semi permanen dan sederhana.

Dari aspek pendidikan, kondisi pendidikan masyarakat Kabupaten Madina jika dilihat dari Komponen Angka Partisipasi Murni (APM) dan Angka Partisipasi Kasar (APK) 
mengalami kemajuan yang cukup menggembirakan karena hampir di setiap komponen pendidikan mengalami kemajuan. Pada Angka Partisipasi Murni (APM) Sekolah Dasar (SD) tahun 2005 hanya mencapai 85.17\% tetapi pada tahun 2010 mencapai 91.13\%. Pada Angka Partisipasi Murni (APM) tingkat Sekolah Menengah Pertama (SMP) tahun 2005 mencapai 77.45\% tetapi pada tahun 2010 mencapai 84.60\%. Pada tingkat SMA (Sekolah Menengah Atas) tahun 2005 mencapai 44.52\% tetapi pada tahun 2010 mencapai 56.70\%. Angka Partisipasi Kasar (APK) Sekolah dasar tahun 2005 mencapai 91.98\% tetapi pada tahun 2010 96.25\%. Angka Partisipasi Kasar (APK) pada Sekolah Menengah Pertama (SMP) mencapai 83.70\% tetapi pada tahun 2010 telah mencapai kemajuan 92.30\%. Angka Partisipasi Kasar (APK) Sekolah Menengah Atas (SMA) tahun 2005 hanya mencapai 55.70\% tetapi pada tahun 2010 telah mencapai kemajuan 59.57\%. Secara umum tingkat pendidikan masyarakat mengalami kemajuan yang cukup signifikan.

\section{Mengenal Kabupaten Pasaman Barat}

Kabupaten Pasaman Barat secara geografis terletak di antara $00^{\circ}, 33$ Lintang Utara$00^{\circ}, 11$ Lintang Selatan dan $99^{\circ}, 10$ sampai $100,00^{\circ}$ Bujur Timur. Garis lintang maksudnya garis khayal untuk menentukan lokasi garis khatulistiwa. Garis bujur adalah untuk mengukur jarak suatu titik di Sebelah Timur dan Barat dari meridian utama. Dari garis lintang dan bujur tersebut akan diketahui tingkat kelembaban udara, kondisi tanah, iklim suatu daerah termasuk di dalamnya musim kemarau dan penghujan.

Secara demografis, jumlah penduduk Kabupaten Pasaman Barat adalah 820.614 jiwa yang tersebar di 11 kecamatan dengan perincian sebagai berikut:

Tabel 2

Jumlah Penduduk

\begin{tabular}{|c|c|c|c|}
\hline \multirow{2}{*}{ Kecamatan } & \multicolumn{3}{|c|}{ Jumlah Penduduk (Jiwa) } \\
\cline { 2 - 4 } & Laki-Laki & Perempuan & $\begin{array}{c}\text { Laki-Laki } \\
\text { Perempuan }\end{array}$ \\
\cline { 2 - 4 } & 2017 & 2017 & 2017 \\
\hline Pasaman & 37.112 & 35.989 & 73.101 \\
\hline Koto Balingka & 14.646 & 14.580 & 29.226 \\
\hline Sungai Aur & 17.955 & 17.532 & 35.487 \\
\hline Lembah Melintang & 23.126 & 23.713 & 46.839 \\
\hline Gunung Tuleh & 10.545 & 10.639 & 21.184 \\
\hline Talamau & 13.618 & 13.405 & 27.023 \\
\hline Luhak Nan Duo & 21.139 & 20.778 & 41.917 \\
\hline
\end{tabular}




\begin{tabular}{|c|c|c|c|}
\hline Sasak Ranah Pasisir & 7.399 & 7.087 & 14.486 \\
\hline Kinali & 35.908 & 34.442 & 70.350 \\
\hline Ranah Batahan & 13.091 & 12.902 & 25.993 \\
\hline Sungai Beremas & 12.671 & 12.030 & 24.701 \\
\hline
\end{tabular}

Didasarkan tabel tersebut di atas, jumlah penduduk terbanyak ditemukan di Kecamatan Pasaman, terbanyak kedua di Kecamatan Kinali, terbanyak ketiga di Kecamatan Lembah Melintang dan terbanyak keempat yaitu di Kecamatan Luhak Nan Duo. Sedangkan jumlah penduduk paling sedikit ditemukan di Kecamatan Sungai Beremas dan Kecamatan Sasak Ranah Pesisir.

Dilihat dari segi etnik, ditemukan lima etnik yang mendiami daerah ini yaitu etnik Minangkabau, Mandailing, Jawa, Batak Toba, Nias. Etnik Minangkabau dan Mandailing merupakan kelompok mayoritas, penduduk pribumi asli. Etnik Jawa adalah masyarakat pendatang, berasal dari program transmigrasi dari Pulau Jawa ditugaskan untuk mukim dan mengelola perkebunan sawit yang dibuka oleh pemerintah daerah pada tahun 1986. Etnik Batak Toba dan Nias juga merupakan etnik pendatang berprofesi sebagai pedagang dan karyawan perkebunan sawit. Sedangkan etnik Tionghoa adalah pemilik perkebunan sawit yang umumnya berprofesi sebagai pedagang dan pengusaha. Izin perkebunan mereka peroleh dari pemerintah daerah, pembelian tanah ulayat atau adat dan tanah masyarakat.

Bahasa yang digunakan di Jorong terdiri atas tiga bahasa yaitu Minangkabau dialek Pasaman, Mandailing dan Jawa. Etnik Mandailing dan Jawa pandai berbahasa Minangkabau dan Mandailing serta sebaliknya etnik Minangkabau dapat memahami bahasa Mandailing. Percampuran bahasa ini tidak dapat dihindari karena telah terjadi akulturasi dan asimilasi antar suku. Melalui pernikahan, paguyuban dan lingkungan alam Minangkabau.

Sahrul, dalam buku Pola Akulturasi Etnik Mandailing dan Minangkabau tahun 2018 menyatakan akulturasi adalah percampuran dua budaya atau lebih antara etnik yang terjadi dalam suatu daerah. Asimilasi ialah percampuran budaya yang menyebabkan hilangnya budaya asli dan menganut budaya baru. Model percampuran budaya tersebut dapat melalui pernikahan antar etnik, ide, simbol, karakter, bahasa, seni, dan pengaruh besarnya budaya lokal terhadap masyarakat perantau. ${ }^{14}$

Dari aspek pendidikan, masyarakat Pasaman Barat adalah masyarakat berpendidikan kalau dilihat dari segi kuantitas lembaga-lembaga pendidikan mulai dari PAUD (Pendidikan Anak Usia Dini), Taman Kanak-Kanak, SD (Sekolah Dasar), Madrasah Ibtidaiyah, Madrasah Tsanawiyah Negeri (MTsN) atau sederajat, Madrasah Aliyah Negeri (MAN), Sekolah Menengah

${ }^{14}$ Sahrul, Pola Akulturasi Budaya Etnik Mandailing dan Minangkabau (Medan: Perdana Publishing, 2018), h. 147. 
Atas (SMA) dan perguruan tinggi. Kini, hampir di setiap jorong ada Sekolah Dasar atau PAUD.

Lebih jelasnya tingkat pendidikan masyarakat dapat dilihat pada tabel sebagai berikut:

Tabel 3

Tingkat Pendidikan Penduduk Pasaman Barat

\begin{tabular}{|c|c|c|c|}
\hline \multirow{2}{*}{ Kecamatan } & \multicolumn{3}{|c|}{ Tingkat Pendidikan (Persen) } \\
\cline { 2 - 4 } & Laki-Laki & Perempuan & $\begin{array}{c}\text { Laki-Laki } \\
\text { Perempuan }\end{array}$ \\
\cline { 2 - 4 } & 2017 & 2017 & 2017 \\
\hline Tidak tamat SD & 26.25 & 25.92 & 26.09 \\
\hline SD/Paket A & 25.41 & 27.95 & 26.66 \\
\hline SMP/Paket B & 23.56 & 21.95 & 22.77 \\
\hline SMA/Paket C & 21.08 & 17.17 & 19.16 \\
\hline DI/DII & 0.23 & 1.20 & 0.71 \\
\hline DIII/Sarjana & 3.23 & 5.32 & 4.26 \\
\hline Sarjana & 0.24 & 0.49 & 0.35 \\
\hline
\end{tabular}

Didasarkan pada tabel tersebut di atas, mayoritas tingkat pendidikan masyarakat Pasaman Barat adalah laki-laki tidak tamat SD (Sekolah Dasar) sebesar 26.25\% dan kaum perempuan sebanyak 25.92\%, laki-laki SD/Paket A sebesar 25.41\% dan kaum perempuan sebanyak 27.92\%, SMP/Paket B laki-laki sebesar $23.56 \%$, perempuan sebanyak 21.95\%, SMA Paket C 21,8\%. Sedangkan tamatan yang paling sedikit ialah sarjana sebanyak 0,24\% dan D1/DII sebanyak 0,23\%.

Rendahnya tingkat pendidikan masyarakat menyebabkan rendahnya sumber daya manusia di tingkat jorong, kenagarian, kecamatan maupun kantor bupati. Hal itu kelihatan tidak sebanding jumlah sarjana dengan besarnya jumlah penduduk sehingga profesi yang banyak ditekuni adalah petani. Petani di sini adalah petani berdasarkan pengalaman saja yang diwariskan oleh nenek moyang. Artinya ilmu pertanian bukan didapat dari bangku perkuliahan.

\section{Kearifan Lokal Etnik Mandailing: Dalihan Na Tolu}

Pada masyarakat enik Mandailing di Kabupaten Madina tidak bisa lepas dari kearifan lokal Dalihan Na Tolu (DNT). Adalah warisan nenek moyang untuk memperkokoh adat dan sosial kemasyarakatan. Dalihan artinya tungku seperti tungku yang digunakan untuk 
memasak. $\mathrm{Na}$ artinya yang (kata penghubung), sedangkan tolu artinya tiga. Secara sederhana dapat dipahami Dalihan Na Tolu maksudnya tungku yang tiga. Jumlah terdiri dari tiga supaya saling bersinergi, tidak boleh empat atau lima tungku. Sebab, kalau digunakan empat atau lima tungku tidak seimbang kekuatannya. Secara logika tungku berkaki lima kelihatan kuat karena saling menopang, tetapi dari segi kekuatan pasti di antara salah satu kaki hanya sebatas pelengkap. Posisi tungku juga harus sama besar, panjang, rendah dan tinggi. Jika ada perbedaan maka salah satu tungku tidak punya kekuatan dan makanan yang dimasak akan tumpah. Posisi periuk bisa juga miring sehingga makanan yang dimasak tidak sempurna masaknya.

Kalau ditafsirkan secara adat, ketiga tungku yaitu terdiri atas mora, kahanggi, dan anak boru. Posisi ini tidak selamanya bersifat mutlak bisa suatu ketika seseorang menjadi anak boru atau kahanggi karena faktor pernikahan. Bahkan siklus ini tidak bisa dihindari karena berkaitan dengan adat istiadat. Apa makna mora? Adalah kelompok yang paling dihormati, barisan para orang tua, tokoh masyarakat. Bisa juga dipahami kelompok kerabat pemberi anak perempuan (boru) untuk dinikahi oleh seorang laki-laki (wife giver). Dalam bahasa Batak Toba mora disebut hulahula.

Kahanggi ialah bisa jadi karena sepupu, ada hubungan darah, kekeluargaan dan satu marga atau padanan marga. Terutama berlaku pada adat etnik Batak Toba. Memang marga-marga di Tapanuli Selatan, Madina, dan Pasaman Barat tidak sama dengan di etnik Batak. Karena itu, untuk mencari titik temu maka dibuatlah padanan marga. Misal, marga Daulay di etnik Mandailing sama dengan marga Silalahi, marga Nasution sama dengan Simanjuntak. Jika bertemu di antara kedua keluarga bisa disebut markahanggi.

Ketika akan diadakan pesta pernikahan, musyawarah adat harus diundang sepupu, semarga yang statusnya adalah kahanggi. Seluruh pelaksanaan pesta merupakan tanggung jawab kahanggi. Suhut pemilik pesta mendelegasikan tugas dan wewenangnya kepada kahanggi terutama berkaitan dengan manajemen pesta (perencanaan, pengorganisasian, penggerakan, pengawasan dan pengevaluasiannya). Posisi suhut menerima laporan tentang suksesnya pelaksanaan pesta.

Anak boru yakni dipahami sebagai menantu (laki-laki dan perempuan). Sering pula dipahami sebagai pekerja di dapur. Sebagai seorang anak boru harus mengetahui posisinya ketika ada pesta pernikahan. Meskipun statusnya dosen, Guru Besar (Prof.), manajer, presiden, menteri, PNS, tukang, TNI/POLRI, pada acara pesta tetap status sosialnya anak boru.

Ditinjau dari segi kedudukan Dalihan Na Tolu, tentu punya peranan penting dalam kehidupan masyarakat. Pertama, untuk menjalin komunikasi yang kokoh antara suhut dengan mora, kahanggi dengan mora, kahanggi dengan anak boru atau anak boru dengan moranya. Tidak boleh satu unsur merasa lebih hebat dan apalagi merendahkan anak boru (menantu). Filosofi yang dibangun adalah berat sama-sama dipikul, ringan sama-sama dijinjing, saling membantu dan saling menghargai. Adat harus dijadikan sebagai alat 
pemersatu dan agama dijadikan sebagai pedoman hidup. Kedua, membangun rasa kasih sayang antara mora, kahanggi dan anak boru. Dari sinilah akan timbul rasa persaudaraan yang kokoh dan saling menghargai. Prinsipnya, mora dan kahanggi adalah benar orang yang harus dimuliakan tetapi posisi anak boru juga harus dihormati meskipun dipandang sebagai halak dapur (orang dapur). Ketiga, penyelesaian konflik andainya terjadi perdebatan, perselisihan dan ketidakcocokan di antara unsur Dalihan Na Tolu. Secara adat yang menyelesaikan permasalahan desa adalah raja, mora dan kahanggi. Sedangkan anak boru (menantu) adalah orang yang siap sedia menerima keputusan mora.

Kalau dihubungkan dengan kedudukan Dalihan Na Tolu dalam menjaga kerukunan antara umat beragama, maka perannya sebagai berikut. Pertama, secara lembaga adat, bahwa posisi Dalihan Na Tolu adalah memiliki posisi sentral dalam kehidupan sosial dan punya pengaruh besar terhadap kedamaian kampung atau desa. Sebab, mora dan kahanggi serta anak boru punya hubungan yang tak dapat dipisahkan saling bersinergi. Kedua, lembaga adat Dalihan Na Tolu bukan hanya sekadar wadah berkumpulnya marga-marga di Mandailing tetapi juga sebagai wadah tempat bermusyawarah di dalam menyelesaikan permasalahan desa termasuk tentang kerukunan antara umat beragama. Ketiga, pengenal garis keturunan yang sering disebut tarombo (silsilah). Ketika seseorang bertemu di pesta pernikahan, kantoran, acara-acara adat dan di kedai kopi harus mengetahui tuturnya. Tidak boleh karena seseorang lebih tua maka dipanggil kakek, tulang, etek, uci dan bapak. Misal adik dari ibu, harus dipanggil tulang, abang dari ayah dipanggil sebutan amang tua (uwak) atau adik dari ayah yang laki-laki dipanggil udak (paman). Kalau dipanggil secara sembarangan maka disebutlah orang yang tak punya adat. Keempat, menerapkan falsafah Dalihan Na Tolu yaitu somba marhula-hula (hormat pada keluarga pihak ibu), elek marboru (ramah dan baik hati pada keluarga perempuan) dan manat mardongan marga (rukun dan baiklah kepada teman semarga). Kelihatannya falsafah inilah yang mempererat hubungan antara sesama anggota masyarakat meskipun beda agama. Kelima, konsep Dalihan Na Tolu memiliki nilai persamaan di antara setiap anggota masyarakat Mandailing dan Batak Toba. Tidak boleh merasa lebih hebat karena kedudukan mora atau kahanggi sementara melihat anak boru dipandang rendah. Didasarkan kepada lima poin tersebut di atas, maka masyarakat semarga, beda marga dan agama tetap dipandang rukun, harmonis dan tidak saling konflik. Alasannya adat sama dipegang, ajaran agama dilaksanakan sehingga terjadi sinkronisasi antara adat dengan budaya. Dalam bahasa Mandailing adat marsombar dohot agama, maksudnya adat sejalan dengan agama.

Dalam upaya merealisasikan hubungan adat dan agama pada etnik Mandailing Natal (Madina) mengandung dua prinsip. Pertama, patik, maksudnya akhlak atau perilaku yang harus dianut secara individu, keluarga dan masyarakat. Kedua, uhum, maksudnya semua masyarakat harus tunduk kepada aturan yang ditetapkan oleh adat. Jika dilanggar diberi sangsi ringan, sedang dan berat. Sangsi berat yaitu dikeluarkan dari anggota adat desa.

Secara agama dan budaya, ditemukan tujuh nilai budaya etnik Mandailing Natal 
untuk menjaga kerukunan umat beragama. Pertama, religius, maksudnya menganut jiwa Islami dalam kehidupan pribadi, keluarga dan masyarakat. Agama harus dijadikan pedoman hidup dan secara fungsional mengatur hubungan pada Allah SWT., sesama manusia dan kepada alam semesta. Kepada Allah bersifat vertikal dan kepada sesama manusia dan alam semesta bersifat horizontal. Ketiga-tiganya harus sejalan kalau tidak manusia jatuh kelembahan kehinaan. Kedua, kekerabatan, maksudnya harus menjaga kekerabatan dengan pihak ayah, ibu dan keluarga jauh bahkan kepada masyarakat kampung. Faktor pembentuk kekerabatan bukan saja karena keturunan tetapi juga bisa faktor agama dan pernikahan. Ketiga, humajuon, maksudnya etnik Mandailing harus maju dalam bidang pendidikan, memiliki sumber daya manusia handal dan menguasai teknologi. Tidak boleh kalah dari etnik lain. Dasar pijakannya ikhtiar, kerja sungguh-sungguh, tidak boleh putus asa, doa dan tawakkal. Keempat, hasangapon, maksudnya harus dibangun rasa saling menghormati di antara setiap kelompok masyarakat, tidak boleh merasa lebih hebat, pintar, kaya dan merendahkan martabat orang lain. Kelima, uhum yaitu berakhlak mulia, menjaga sopan santun dan mematuhi seluruh aturan yang ditetapkan oleh lembaga adat, kepala desa atau pemerintah. Keenam, pengayom artinya melindungi kepada siapa saja bukan saja kepada keluarga, sahabat, seagama dan bahkan beda agama. Ketujuh, kelola konflik. Maksudnya secara sosial masyarakat tidak bisa lepas dari konflik keluarga, tetangga dan sesama anggota masyarakat. Karena itu, harus dijunjung tinggi kesadaran hukum meliputi patik, uhum dan laksanakan hak dan kewajiban. Jangan hanya pandai meminta hak tetapi tidak menunaikan kewajiban.

Dalam mengelola konflik sosial etnik Mandailing adalah pengayom sejati. Mora harus menjadi pengayom kepada kahanggi dan begitu juga kepada anak borunya. Sebaliknya anak boru juga harus menghormati barisan kahanggi dan moranya. Mengapa demikian penting mengatasi konflik sosial di masyarakat? Sebab, dalam pandangan etnik Mandailing konflik itu adalah aib. Dampaknya, membuat malu di tengah-tengah masyarakat dan merusak nama baik keluarga. Di samping itu, tidaklah menggambarkan akhlak mulia. Munculnya pemahaman ini dipengaruhi oleh ajaran Islam.

\section{Kearifan Lokal Etnik Minangkabau: Ninik Mamak dan Kerapatan Adat Nagari}

Ninik Mamak adalah pemuka adat sering juga disebut datuk. Dalam tradisi Melayu disebut penghulu, pada etnik Mandailing adalah ketua adat (harajaon). Perkataan dan perbuatan Ninik Mamak didengar dan ditaati oleh masyarakat jorong. Ada juga yang memahami Ninik Mamak ialah lembaga adat yang terdiri atas beberapa penghulu ${ }^{15}$ yang

\footnotetext{
${ }^{15}$ Penggunaan istilah penghulu sebenarnya berbeda dengan Ninik Mamak. Dalam tradisi etnik Mandailing, penghulu identik dengan kepala kampung (kepala desa), namun ada juga yang mengatakan penghulu adalah tuan kadi. Tugasnya adalah menikahkan laki-laki dan perempuan yang telah memenuhi syarat dan rukun nikah.
} 
berasal dari klan/suku, biasanya lebih senior, dipandang cakap, amanah, berwawasan luas, berintegritas dan bijaksana dalam memimpin.

Jabatan Ninik Mamak bukanlah dipilih oleh masyarakat tetapi ditetapkan berdasarkan musyawarah jorong, keturunan raja dan dilantik oleh wali nagari. Karena itu, jabatan Ninik Mamak bersifat turun temurun, jika ayah meninggal maka jabatan Ninik Mamak diteruskan oleh anak. Demikianlah seterusnya, hal yang tidak dibolehkan Ninik Mamak berasal dari kaum wanita. Jika misalnya Ninik Mamak tidak punya keturunan anak laki-laki maka jabatan Ninik Mamak diserahkan kepada keluarga lain yang punya pertalian darah dan masih satu marga. Misal kalau di suatu jorong Ninik Mamak marga Nasution maka selama jorong tetaplah marga Nasution. Kalau ada kelompok marga lain yang ingin menjadi Ninik Mamak maka harus melalui upacara adat dengan syarat harus memotong kerbau.

Di Pasaman Barat ada tiga versi cara penetapan Ninik Mamak. Pertama, dari garis keturunan ibu dan dialah yang bertanggung jawab kepada kemanakannya. Model ini dianut oleh etnik Minangkabau. Kedua, berdasarkan garis keturunan ayah hal itu diterapkan etnik Mandailing. Sebab, laki-laki adalah kepala keluarga, penerus dan pewaris keluarga. Ketiga, berdasarkan keturunan orang pertama yang merintis jorong. Sebagai bentuk penghargaan maka diberi jabatan Ninik Mamak.

Versi lain, Ninik Mamak memiliki empat makna. Pertama, adik laki-laki dari ibu disebut mamak. Kedua, Laki-laki yang telah baligh atau dewasa yang dapat diajak berpikir rasional dan terbuka. Ketiga, laki-laki yang dituakan dalam lingkup keluarga bisa menjadi panutan karena faktor senioritas. Keempat, Pengetua adat, imam khatib, alim ulama, cerdik pandai dan bunda kandung (penghuni rumah gadang). ${ }^{16}$

Ketiga cara pengambilan Ninik Mamak tersebut di atas tidak ada masalah secara adat dan cukup tergantung pada etniknya. Bahkan sampai sekarang belum pernah terjadi konflik sosial karena perebutan posisi Ninik Mamak kecuali di kalangan keluarga Ninik Mamak sendiri. Sebab, di antara bersaudara ada keinginan kadang-kadang yang lebih tua dan lebih tinggi tingkat pendidikannya. Hal itu dipandang masih dalam batas kewajaran dan manusiawi.

Didasarkan kepada data Kantor Bupati Pasaman Barat terdapat 202 Ninik Mamak kalau dihitung perjorong. Tergolong jumlah besar dan merupakan sebuah kekuatan utama dalam menjaga kerukunan jorong maupun kerukunan antar umat beragama. Menurut penjelasan Nasrun Nasution, kepemimpinan Ninik Mamak adalah kepemimpinan tradisional, estapet (berkesinambungan) ibarat pepatah: patah tumbuh hilang berganti.

Meskipun disebut kepemimpinan estafet, ada beberapa syarat menjadi Ninik Mamak. Pertama, beriman kepada Allah SWT. Kedua, pandai membaca al-Qur'an sebagai kitab

${ }^{16}$ Wawancara dengan Bakaruddin, Ninik Mamak Kecamatan Kinali, 28 Juli 2018. 
suci umat Islam yang diwahyukan kepada Nabi Muhammad SAW. dan dijadikan sebagai pedoman hidup. Ketiga, berakhlak mulia. Keempat, memahami seluk beluk adat di jorong; Minangkabau, Mandailing dan Jawa. Kelima, loyal artinya setia kepada masyarakat jorong, para ulama dan kepada tokoh-tokoh masyarakat. Keenam, cerdas artinya berpikir rasional dan punya terobosan baru untuk membangun masyarakat jorong. Ketujuh, punya kemampuan manajerial (memimpin, mengorganisir kegiatan jorong, melakukan penggerakan dan pengevaluasian). Kedelapan, mampu menjalin kerjasama dengan pihak luar terutama untuk membangun masyarakat jorong ke arah yang lebih maju. Kesembilan, diterima oleh masyarakat jorong, nagari dan kerapatan adat nagari.

Sedangkan fungsi Ninik Mamak, digambarkan dalam sebuah pepatah: Seperti kayu besar di tengah padang yang luas, tempat berlindung dari sengatan sinar matahari, tempat berteduh ketika hujan turun, akarnya tempat bersila kaki, batangnya tempat bersandar, pergi tempat bertanya dan pulang membawa kabar berita. ${ }^{17}$

Didasarkan pepatah tersebut di atas, ada dua fungsi Ninik Mamak secara adat. Pertama, sebagai pelindung dan pembimbing terhadap anak dan kemanakan dalam keluarga dan masyarakat. Sebab, dalam kehidupan keluarga dan masyarakat banyak masalah yang dihadapi oleh anak dan kemanakan terutama berkaitan dengan masalah keluarga dan sosial. Seorang Ninik Mamak dituntut dapat memberi bimbingan agar anak dan kemanakan tersebut sukses menjalani kehidupan, rukun atau akur di masyarakat. Kedua, tempat bertanya. Posisi Ninik Mamak yang amat terhormat harus dijadikan sebagai tempat bertanya tentang adat, permasalahan sosial dan keluarga.

Menurut Bustami, dulu benar fungsi Ninik Mamak terbatas pada masalah adat dan keluarga kemanakan. Namun, kini seiring dengan berkembangnya wilayah Pasaman Barat justru fungsinya diperluas sebagai tempat bertanya dan pemberi solusi sosial di jorong. ${ }^{18}$ Karena itu, seorang Ninik Mamak harus memahami seluk beluk adat; pandai memulai acara adat, memahami tata cara meminang, marhata-hata atau markobar (berbicara), dan memberi kata nasihat. Posisi tempat duduknya ditempatkan pada tempat terhormat. Sebuah bentuk tradisi di jorong acara adat tidak akan dimulai sebelum dihadiri oleh oleh Ninik Mamak. Pada sisi lain, harus orang yang bijak sehingga dapat menyelesaikan permasalahan sosial di setiap jorong.

Secara sosial, fungsi Ninik Mamak meliputi empat hal. Pertama, menjadi hakim pendamai jika terjadi konflik sosial di masyarakat. Tugas ini seperti digambarkan dalam sebuah pepatah, sebagai berikut:

Kusuik manyalasaikan masalah (Kusut menyelesaikan masalah). Karuih manjarniahkan (Keruh dijernihkan). Luruih bana dipegang taguih (Kalau sudah lurus harus dipegang teguh). Tibo di mato indak dipiciangkan (Tiba di mata tidak boleh dipicingkan). Tibo

\footnotetext{
${ }^{17}$ Wawancara dengan Bustami, tokoh adat Pasaman Barat, 28 Agustus 2018.

${ }^{18}$ Wawancara dengan Bustami, tokoh adat Pasaman Barat, 28 Agustus 2018.
} 
diparuik indak dikampiskan (Tiba diperutkan tidak boleh dikempiskan). Harus luruih sadonya (harus lusrus semuanya).

Tafsir sosial atas pantun tersebut di atas, seorang kepala jorong bukanlah bagian dari masalah tetapi dapat menyelesaikan masalah. Harus berpikir cerdas dan objektif meskipun masalah itu terjadi dalam lingkup keluarga. Tiba di mata tidak boleh dipicingkan dan tiba diperut tidak boleh dikempiskan. Artinya harus berlaku adil kepada siapapun. Makna adil ialah menempatkan sesuatu pada tempatnya.

Kedua, kontrol sosial. Maksudnya menjadi pengawas terhadap perbuatan-perbuatan mungkar yang bertentangan dengan ajaran agama, adat dan norma. Sebab, di jorong dewasa ini beragam perilaku para remaja menyimpang yang dipengaruhi oleh faktor lingkungan, pergaulan, kemajuan dunia internet, dan perubahan sosial. Segala bentuk perubahan sosial tidak bisa dihindari oleh masyarakat kota dan jorong karena kemajuan teknologi informasi telah menjangkau seluruh lapisan masyarakat. Tanpa meminta izin sudah masuk ke dalam rumah melalui media televisi. Di samping itu, hampir semua generasi muda menggunakan handphone bahkan lebih akrab dari pada al-Qur'an sebagai kalam Allah SWT. Sekarang, untuk menghindari diri dari kerusakan moral sangat tergantung niat, kemauan dan harus kokoh pendidikan agama dalam rumah tangga. Hal itulah yang merupakan bagian dari tugas para Ninik Mamak.

Ketiga, menghindari terjadi persekusi di masyarakat. Persekusi maksudnya tindakan menyakiti orang lain karena berbeda pendapat, berbeda keyakinan, dendam dan mengejek tokoh panutannya. Perilaku ini era belakangan sering terjadi di masyarakat dan bertentangan dengan nilai-nilai sosial. Mungkin hanya masalah sederhana misal karena batas tanah, air sawah, masalah muda mudi dan anaknya dihina.

Keempat, membentuk masyarakat yang harmonis dan rukun antara seetnik, beda etnik, latar belakang sosial, wilayah, beda status sosial dan beda agama.

Secara agama, fungsi Ninik Mamak. Pertama, menjaga generasi muda agar tidak murtad (pindah agama). Sebab, masa sekarang beragam cara dilakukan oleh para misionaris untuk memurtadkan umat Islam terutama melalui pernikahan beda agama. Cara lain, yakni menambah surat al-Qur'an, kesaksian palsu dari mantan muslim (murtaddin), dan kegiatan sosial di desa-desa terpencil. Kedua, mengantisipasi berkembangnya paham terorisme dan radikalisme di masyarakat. Ketiga, menjaga kerukunan antarumat beragama. Rukun artinya harmonis, damai dan bersahabat dalam perbedaan. Fungsi inilah yang sedang dilakukan oleh para Ninik Mamak di Pasaman Barat. Meskipun diakui ada pendirian gereja tanpa izin bangunan, rumah dijadikan gereja, berdiri gereja di perkebunan sawit dan di lingkungan pemukiman muslim. Sebagai lembaga adat, turut serta menciptakan suasana sosial yang akur dan meminimalisir terjadi gesekan sosial. Menurut penjelasan kepala kantor Kementerian Agama Pasaman Barat, posisi Ninik Mamak di masyarakat berperan aktif melakukan dialog agama, tidaklah berdiam diri, setelah ada peristiwa baru diadakan dialog. 
Secara agama dan sosial, permasalahan pendirian gereja di Pasaman Barat cukup mengganggu keharmonisan hubungan antarumat beragama. Pemerintah daerah tidak bisa sendirian mengambil kesimpulan tetapi melakukan pendekatan melalui unsur Ninik Mamak. Bahkan di kalangan remaja masjid dan pemuda organisasi Islam muncul sikap yang lebih ekstrim harus merobohkan gereja dengan jalan kekerasan dan intimidasi. Namun, di kalangan Ninik Mamak tindakan kasar, dan keras justru akan menambah permasalahan baru di masyarakat. Di samping itu, tidak sesuai dengan landasan kerukunan hidup antarumat beragama yaitu Pancasila dan Undang-Undang Dasar tahun 1945.

Pertama, Pancasila yaitu sila pertama Ketuhanan Yang Maha Esa. Berarti mengakui semua agama di Indonesia yaitu Islam, Kristen Katolik, Protestan, Hindu, Buddha dan Konghucu. Untuk memperkokoh pernyataan ini dicantumkan dalam GBHN (Garis-garis Besar Haluam Negara) TAP MPR. IV tanggal 23 Maret 1973 di Jakarta, berisi bahwa: (1) Atas dasar kepercayaan bangsa Indonrsia terhadap Tuhan Yang Maha Esa maka peri kehidupan beragama dan peri kehidupan terhadap kepercayaan terhadap Tuhan Yang Maha Esa sesuai dengan falsafah Pancasila. (2) Pembangunan agama dan kepercayaan terhadap Tuhan Yang Maha Esa ditujukan untuk pembinaan suasana hidup rukun di antara sesama umat beragama, semua penganut kepercayaan terhadap Tuhan Yang Maha Esa serta meningkatkan amal dan membangun masyarakat bersama-sama.

Kedua, Undang-Undang Dasar 1945 pasal 28 E sebagai berikut: Ayat (1) Setiap orang bebas memeluk agama dan beribadat menurut agamanya, memilih pendidikan dan pengajaran, memilih pekerjaan, memilih kewarganegaraan, memilih tempat tinggal di wilayah negara dan meninggalkannya serta berhak kembali. Ayat (2) Setiap orang berhak atas kebebasan meyakini kepercayaan, menyatakan pikiran dan sikap sesuai dengan hati nuraninya. Ayat (3). Setiap orang berhak atas kebebasan berserikat, berkumpul dan mengeluarkan pendapatnya.

Lebih lanjut ditegaskan pada BAB XI tentang Agama. Pasal 29 yaitu: Pasal (1) Negara berdasar atas Ketuhanan Yang Maha Esa. Pasal (2) Negara menjamin kemerdekaan tiaptiap penduduk untuk memeluk agamanya masing-masing dan untuk beribadat menurut agama dan kepercayaannya itu.

Dalam membantu menjaga kerukunan antarumat beragama, Ninik Mamak dan Kerapatan Adat Nagari (KAN) membangun komunikasi dengan FKUB (Forum Kerukunan Umat Beragama). Terutama terkait dengan tiga hal. Pertama, kerukunan internal umat beragama (seagama). Pada kenyataannya di kalangan penganut agama yang sama sering juga terjadi konflik atau pertentangan. Misalnya pertentangan antara ormas Islam Muhammadiyah, Nahdlatul Ulama, Front Pembela Islam (FPI), PERSIS, Al-Ittihadiyah, dan Dewan Dakwah Islam (DDI). Dampaknya cukup membingungkan pengikut dan umat Islam. Karena itu, diperlukan upaya sungguh-sungguh untuk menjalin komunikasi satu sama lain. Landasannya akidah, syahadatain, rukun iman dan Islam sama. Kedua, kerukunan antarumat beragama. Pedoman dasar tentang kerukunan antarumat beragama 
telah diatur dalam Surat Keputusan Bersama yang ditanda tangani oleh Menteri Agama dan Menteri Dalam Negeri nomor 8 dan 9 tahun 2006. Di antara isinya berkaitan dengan toleransi antarumat beragama yaitu saling menghormati dan menghargai ajaran masingmasing agama, menghormati atau tidak melecehkan simbol-simbol maupun kitab suci masing-masing agama, dan tidak mengotori atau merusak tempat ibadah agama orang lain serta ikut menjaga ketertiban dan ketenangan kegiatan keagamaan. Ketiga, kerukunan antarumat beragama dengan pemerintah. Pemerintah sebagai pelindung terhadap semua agama diharapkan bersikap netral atau tidak memihak terhadap semua pemeluk agama di tanah air. Posisi netral ini tentu akan menciptakan keharmonisan di kalangan penganut agama. Untuk merealisasikannya maka perlu pemahaman yang mendalam tentang Pancasila sebagai dasar negara dan Undang-Undang Dasar 1945 sebagai landasan konstitusional.

Didasarkan hasil wawancara dengan ketua FKUB (Forum Kerukunan Antarumat Beragama) Kabupaten Pasaman Barat, Ninik Mamak secara adat, sosial dan agama telah menjalankan fungsinya dalam menjaga kerukunan antarumat beragama di Pasaman. Meskipun posisi mereka dalam pandangan sebagian masyarakat justru pemicu konflik agama dan sosial bukan menjadi alat "pemadam kebakaran."

\section{Kerapatan Adat Nagari}

Secara lembaga, Kerapatan Adat Nagari (KAN) adalah atasan dari para Ninik Mamak yang ada di jorong. Kantornya terpisah dengan wali nagari dan berdiri sendiri. Ada juga yang mengatakan merupakan mitra kerja dari wali nagari dalam bidang adat, sosial dan agama. Unsur-unsurnya terdiri atas Ninik Mamak, alim ulama, cerdik pandai (intelektual), dubalang.

Secara bahasa, kata alim ulama terdiri atas dua kata yaitu alim dan ulama. Alim dimaknai adalah orang yang kuat pengamalan agama, akhlak mulia dan sesuai antara perkataan dan perbuatan. Ulama yaitu orang dalam ilmu pengetahuan agama baik dari segi ilmu al-Qur'an, hadis, bahasa Arab, ilmu tauhid dan fikih. Di jorong, disebut malim kampung, sering juga dikatakan imam kotik (imam khatib). Tugasnya yakni mengurusi bidang keagamaan. Kedudukannya cukup terhormat karena seluruh kegiatan berkaitan dengan masalah agama merupakan tanggung jawabnya seperti imam salat di masjid, mengurusi pengajian anak-anak, remaja, bilal jenazah dan hingga majelis taklim. Kini, tugasnya diperluas sebagai tokoh agama, pembimbing rohani dan pengontrol perbuatan buruk masyarakat dan para pemimpinnya.

Secara adat, alim ulama panutan lahir dan batin, bagaikan lampu penerang dalam nagari, penyuluh agama kepada anak dan kemanakan di jorong, tempat bertanya tentang halal dan haram bagi masyarakat, penunjuk jalan di dunia dan kehidupan di akhirat. Filosofi yang dianut "adat basandi syarak, syarak basandi kitabullah (al-Qur'an dan Sunnah)".

Pengangkatan seorang alim ulama di jorong dan kenagarian tidaklah didasarkan 
keinginan kepala jorong dan wali nagari tetapi harus memiliki syarat-syarat, yaitu beriman dan bertakwa kepada Allah SWT., berakhlak mulia, ikhlas dalam berbuat, tawaduk (rendah hati), pemaaf, istikamah, amanah, bertanggung jawab, dan berwawasan luas.

Idealnya, seluruh syarat tersebut di atas harus dimiliki oleh seorang alim ulama. Di jorong batas minimal yang diharapkan yakni beriman, berakhlak mulia, ikhlas, tawaduk, amanah dan berwawasan luas. Sebab, di jorong sulit ditemukan orang yang benarbenar ulama. Paling tidak untuk ukuran jorong sudah tergolong memadai.

Dalam upaya mendukung fungsi ulama di jorong, pemerintah daerah juga sekarang membuat program dai masukjorong. Tujuannya adalah pemberdayaan dai secara konvensional menuju dakwah profesional. Kegiatan keagamaan harus membumi di masyarakat, mengantisipasi dan mengatasi masalah sosial, ekonomi, pendidikan dan agama yang kelihatan dewasa ini semakin kompleks seiring dengan majunya Pasaman Barat dari segi eknomi dan perubahan sosial.

Cerdik pandai yakni kelompok intelektual. Dalam bahasa Minangkabau cerdik yaitu cadiak, artinya cerdas, pandai artinya kreatif. Kedudukannya hampir sama dengan alim ulama yakni pelindung dan pembimbing masyarakat, tempat bertanya dan meminta pendapat dalam berbagai masalah sosial terutama yang berkaitan dengan masalah undang-undang dan peraturan. Disebut cerdik pandai karena memiliki kemampuan lebih dari anggota masyarakat biasa. Atas kecerdasannya maka diberi nama cerdik pandai dan diangkat menjadi unsur pemimpin informal. Ia menjadi tokoh panutan, dihormati dan segala perkataan dan perbuatannya menjadi cermin di jorong dan nagari.

Didasarkan pada hasil wawancara dengan Bustami dan Bakaruddin Nasution ada beberapa fungsi kaum cerdik pandai di Pasaman Barat. Pertama, pelindung yang kuat (cadiak pandai pamaga kokoh). Karena kemampuan intelektualnya mumpuni. Betapa pun hebatnya tantangan dan hambatan yang dihadapi jorong maupun kenagarian kalau kaum cerdik pandai, hebat dan intelektual, semua masalah dapat diatasi. Kedua, benteng bagi korong kampung (pamaga korong dengan kampung). Maksudnya menjadi benteng yang kokoh untuk mempertahankan eksistensi jorong dari gangguan pihak kampung lain. Ketiga, Pamaga adat dan ugamo (pelindung adat dan agama). Maksudnya adat harus tetap dipertahankan dan disesuaikan dengan ajaran agama, seluruh perbuatan adat mengandung unsur syirik harus dibuang. Demikian pula tingkah laku masyarakat yang tidak mencerminkan akhlak Islam harus ditentang karena tergolong perbuatan mungkar. Contoh kawin sejenis yang terjadi di jorong Ujung Gading, Kecamatan Lembah Melintang Oktober 2018. Keempat, pamaga anak dan kemanakan. Maksudnya menjadi pelindung dan pembimbing terhadap anak dan kemanakan dari berbagai pengaruh lingkungan dan pergaulan bebas yang dapat merusak masa depannya. Kelima, pamaga balai dan musojik, maksudnya sebagai benteng atas balai (tempat pertemuan) dan masjid. Bagi masyarakat Pasaman Barat balai harus dijaga kelestariannya dan masjid harus dijaga kesuciannya 
karena merupakan rumah ibadah. Keenam, pamaga budi baik, maksudnya sebagai benteng terhadap perangai, tingkah laku di masyarakat. Jika ada perilaku menyimpang yang bertentangan dengan ajaran Islam dan budaya maka cerdik pandai harus cepat bertindak. Ketujuh, pamaga terhadap budaya malu, maksudnya kaum cerdik pandai harus menjadi benteng yang kokoh untuk menjaga budaya malu di masyarakat. Sebab, di tengah meningkatnya perubahan sosial dan kemajuan teknologi sebagian masyarakat merasa tidak malu mengumbar aurat, pergaulan bebas dan bahkan tidak malu kalau tidak mengikuti pengajian di masjid.

Dubalang adalah pembantu penghulu atau Ninik Mamak dalam menjaga ketertiban dan keamanan jorong. Dulu dikenal dengan istilah hulubalang. Syarat menjadi dubalang ialah pemberani. Prinsip hidupnya adalah kareh ditakiak, lunak disudu, artinya apapun mereka lakukan untuk menjaga ketentraman jorong atau kampung.

Seiring dengan kemajuan jorong, kini dubalang identik dengan pemuda jorong yang diberi amanah untuk menjaga keamanan dan ketertiban masyarakat termasuk di dalamnya menjauhkan masyarakat dari konflik sosial. Keempat serangkai inilah yang saling bahu membahu membangun dan menjaga masyarakat nagari.

Menurut Bustami, fungsi KAN (Kerapatan Adat Nagari) sebagai penyelesai sengketa tanah ulayat di jorong dan kenagarian, untuk menampung seluruh aspirasi dan permasalahan adat dan sosial baik diajukan maupun tidak diajukan oleh masyarakat nagari. Secara sosial tugasnya adalah untuk menciptakan suasana sosial yang akrab dan harmonis antara korong kampung (desa) dan andainya terjadi ketidakakuran sosial maka Kerapatan Adat Nagari (KAN) harus menjadi seperti kayu besar, pelindung dan pengayom di masyarakat. Apabila setiap tugas dilaksanakan maka di setiap nagari di Pasaman Barat tercapailah tujuan seperti diungkapkan dalam sebuah pepatah "Elok nagari dek penghulu, elok musojik dek tuangku dan elok masyarakat karena cadiak pandai dan dubalang." Maksudnya, bagus (elok) nagari karena penghulu, dan bagus (elok) masjid karena pemuka agama, dan bagus ketenteraman masyarakat karena cerdik pandai dan dubalang. ${ }^{19}$

Peranan dari empat elemen Kerapatan Adat Nagari (KAN) dan Forum Komunikasi Islam (FKOI) yang cukup besar kontribusinya dalam menjaga ketertiban umum. Misalnya melakukan pembubaran kebaktian gereja Huria Batak Protestan (HKBP), di Pospel Plasma Pasaman Kecamatan Kinali tanggal 25 Pebruari 2018 karena gereja tersebut tidak punya Izin Mendirikan Bangunan (IMB). Kasus ini juga sudah terjadi sebelumnya yaitu pada tahun 2013 dan 2014. Karena penganut agama Kristen tidak punya Izin Mendirikan Bangunan (IMB) gereja dari pemerintah daerah maupun lembaga adat Minangkabau.

\section{Penutup}

Kearifan lokal Dalihan Na Tolu di Kabupaten Mandailing Natal (Madina) kelihatan

${ }^{19}$ Wawancara dengan Bustami, tokoh adat Kabupaten Pasaman Barat, 30 Juli 2018. 
cukup kuat perannya dari segi adat dan sosial dalam menjaga kerukunan antarumat beragama. Karena dalam kehidupan sosial menerapkan tujuh konsep budaya, yaitu religius (Islami) dalam kehidupan pribadi, keluarga dan masyarakat, menjaga kekerabatan antara keluarga, tetangga, sahabat dan masyarakat berbeda agama, hamajuon, selalu berpikir maju, rasional, cerdas, berpendidikan dan menguasai ilmu pengetahuan dan teknologi, hasangapon yaitu membangun sikap saling menghormati baik secara individu, keluarga dan masyarakat, uhum yaitu peraturan yang mengikat seluruh anggota masyarakat dan tidak boleh dilanggar. Andainya dilanggar maka akan diberi sangsi ringan, sedang dan berat yaitu dikeluarkan dari masyarakat adat, pengayom maksudnya mora, kahanggi dan anak boru harus saling mengayomi, tidak boleh karena kedudukannya terhormat menganggap kelompok lain rendah status sosialnya. Demikian kepada setiap pemimpin harus mengayomi masyarakat bukan untuk diayomi, dan kelola konflik yaitu setiap terjadi konflik di masyarakat harus dicari jalan keluar di kalangan seagama, beda agama, suku maupun antara warga. Kalau tidak bisa diatasi bagi masyarakat Mandailing adalah sebuah aib yang memalukan.

Peranan Ninik Mamak dan Kerapatan Adat Nagari (KAN) di Kabupaten Pasaman Barat belum sepenuhnya optimal melaksanakan fungsinya di dalam menjaga kerukunan antarumat beragama terutama berkaitan dengan minimnya dialog agama dan kerjasama dengan FKUB (Forum Kerukunan Umat Beragama). Di samping itu, sampai kini belum berhasil menghentikan pembangunan gereja. Kendala-kendala di antaranya sifat eksklusif dari masing-masing pemeluk agama (Islam dan non Islam), fanatisme agama, perbedaan suku, rumah dijadikan sebagai gereja, didirikan gereja tanpa Izin Mendirikan Bangunan (IMB) dan Forum Kerukunan Umat Beragama (FKUB) belum optimal menjalankan fungsinya.

\section{Pustaka Acuan}

Abdullah, M. Amin. Studi Agama. Yogyakarta: Pustaka Pelajar, 1996.

Agus, Bustanudin. Agama Dalam Kehidupan Manusia. Jakarta: Rajawali Press, 2006.

Bungin, M. Burhan. Penelitian Kualitatif. Jakarta: Kencana, 2007.

Chandra, Ade, et al. Minangkabau Dalam Perubahan. Padang: Yasmin Akbar, t.t.

Harahap, Basyral Hamidy. Madina yang Madani. Madina: Panyabungan, 2004.

Hilda, Lelya. "Revitalisasi Kearifan Lokal Dalihan Na Tolu Masyarakat Muslim Mandailing Dalam Menjaga Harmonisasi Lingkungan Hidup," dalam MIQOT: Jurnal Ilmu-ilmu Keislaman, Vol. 42, No. 2, 2018.

Ja'far, Ja'far. "Tarekat dan Gerakan Sosial Keagamaan Shaykh Hasan Maksum,” dalam Teosofi: Jurnal Tasawuf dan Pemikiran Islam, Vol. 5, No. 2, 2015.

Ja'far, Ja'far. "Peran Al Jam'iyatul Washliyah dalam Merevitalisasi Madhhab Shafi'i di Era Kontemporer," dalam Justicia Islamica: Jurnal Kajian Hukum dan Sosial, Vol. 13, No. 1, 2016. 
Ja'far, Ja'far. "Respon Dewan Fatwa Al-Jam'iyatul Washliyah Terhadap Isu Akidah dan Syariah di Era Global," dalam Al-Manahij: Jurnal Kajian Hukum Islam, Vol. 10, No. $1,2017$.

Jafar, Jafar. "Al Jam'iyatul Washliyah dan Problem Kepemimpinan Non Muslim dan Perempuan," dalam Ahkam: Jurnal Ilmu Syariah, Vol. 17, No. 2, 2017.

Ja'far, Ja'far. “Respons Al Jam'iyatul Washliyah Terhadap Terorisme,” dalam Akademika: Jurnal Pemikiran Islam, Vol. 22, No. 1, 2017.

Jamaludin, Adon Nasrullah. Agama dan Konflik Sosial. Bandung: Pustaka Setia, 2015.

Kahmad, Dadang. Sosiologi Agama. Bandung: Rosdakarya, 2002.

Lubis, Z. Pangaduan. Asal Usul Marga-Marga di Mandailing. Medan: Mitra, 2010.

Lubis, Z. Pangaduan. Sipirok Nasoli: Bianglala Kebudayaan Masyarakat Sipirok. Medan: USU Press, 1998.

Nasution, Pandapotan. Adat Budaya Mandailing Dalam Tantangan Zaman. Medan: Porkala, 2005.

Pelly, Usman. Urbanisasi dan Adaptasi Peranan Misi Budaya Minangkabau dan Mandailing. Jakarta: LP3ES, 1994.

Pulungan, Abbas. "Nahdlatul Ulama di Luar Jawa: Perkembangan di Tanah Mandailing," dalam Journal of Contemporary Islam and Muslim Societies, Vol. 2 No. 1, 2018.

Rajamarporang, D.J. Gultom. Dalihan Na Tolu Nilai Budaya Suku Batak. Medan: Armanda, 1992.

Sadiah, Dewi. Metode Penelitian Dakwah. Jakarta: Kencana, 2007.

Sahrul. Agama dan Masalah-Masalah Sosial. Bandung: Citapustaka Media, 2016.

Sahrul. Akulturasi Budaya Etnik Mandailing Dengan Minangkabau di Pasaman Barat. Medan: Citapustaka Media, 2018.

Sahrul. Sosiologi Islam. Medan: IAIN Press, 2011.

Sihombing, Adison Adrian. "Mengenal Budaya Batak Toba Melalui Falsafah "Dalihan Na Tolu" (Perspektif Kohesi dan Kerukunan)," dalam Jurnal Lektur Keagamaan, Vol. 16, No. 2, 2018.

Simanjuntak, Panyaman J. Pedoman Pelaksanaan Dalihan Na Tolu. Jakarta: Puri Mandiri, 1996.

Soekanto, Soerjono. Sosiologi Suatu Pengantar. Jakarta: Rajawali Press, 1996.

Sumarti, Beti. Revitalisasi Peran Ninik Mamak Dalam Pemerintah Nagari. Yogyakarta: Fisipol UGM, 2010.

Sumbulah, Umi dan Nurjanah. Pluralisme Agama. Malang: UIN Maliki, 2013.

Sunarto, Kamanto. Pengantar Sosiologi. Jakarta: Fakultas Ekonomi UI, 2004.

Suwarna. UUD 1945 Plus UUD di Indonesia dan Lembaga Tinggi Negara. Jakarta: Limas, 2014. 
Sahrul \& Afrahul Fadhila Daulai: Kearifan Lokal Dalihan Na Tolu, Ninik Mamak

Suyanto, Bagong dan J. Dwi Narwoko (ed.). Sosiologi Teks dan Pengantar dan Terapan. Jakarta: Kencana, 2004.

Syahnan, Mhd. "Nahdlatul Ulama Scholar in Mandailing Land: A Biography of Shaykh Ali Hasan Ahmad ad-Dary," dalam Journal of Contemporary Islam and Muslim Societies, Vol. 3 No. 1, 2019. 